\title{
Mechanisms of Weight Loss after Gastric Bypass and Gastric Banding
}

\author{
Marco Bueter Hutan Ashrafian Carel W. le Roux \\ Department of Investigative Medicine, Hammersmith Hospital, Imperial College London, UK
}

\section{Key Words}

Obesity · Gut hormones · Gastric bypass .

Hypothalamus · Appetite - Satiety

\section{Summary}

The obesity epidemic is a major health problem that is associated with increased morbidity and mortality. Gastrointestinal hormones have been increasingly understood to be an important element in appetite regulation. Several gastrointestinal hormones can contribute to obesity by modulating the activity of the gut-brain axis. Bariatric surgery is currently the most effective therapy for significant and sustained weight loss in morbidly obese patients. Understanding how gut hormones are altered by bariatric procedures has contributed to our understanding of the mechanisms of appetite. In this review, we address several gastrointestinal hormones that are associated with obesity and consider how their levels are altered after bariatric surgery. The review also addresses specific effects of different gut hormones on appetite, hunger, and energy balance.

\section{Introduction}

The personal, social, and economic consequences of the obesity epidemic can be devastating [1-3]. Major research efforts are being directed towards the development of successful weight loss therapies. Consequently, the neuroendocrine regulation of food intake and weight gain has been increasingly studied. This is especially the case for gut hormones that may have future pharmacotherapeutic applications [4-6]. At this stage, the available anti-obesity drugs are moderately effective at achieving weight loss, whilst their side-effects remain problematic. The most effective therapeutic option currently available to obtain significant and sustained weight loss is bar- iatric surgery $[7,8]$. The exact mechanisms involved in weight loss after these surgical techniques are not completely understood, but a number of studies have demonstrated that alterations in circulating gut hormone levels may play an important role [9-11]. There is a growing body of evidence suggesting that gut hormones may be involved in transmitting information from the gastrointestinal tract to the appetite centres in the central nervous system (CNS) as part of the gut-brain axis. Alterations in these hormones after bariatric procedures may partly explain the mechanisms by which surgery reduces appetite and induces sustained weight loss.

\section{Basic Principles of Common Bariatric Procedures}

Bariatric procedures are surgical procedures performed to treat obesity through modification of the gastrointestinal tract. Surgical procedures for the removal of body fat such as liposuction or abdominoplasty are not considered as bariatric surgical procedures as their weight loss is small and unsustained. The National Institute of Clinical Excellence (NICE) criteria for bariatric surgery recommends patients to be eligible for surgical procedures if they have a BMI $\geq 35 \mathrm{~kg} / \mathrm{m}^{2}$ with an obesity-related comorbidity or patients with a BMI $\geq 40 \mathrm{~kg} / \mathrm{m}^{2}$. Patients need to have an instituted but failed adequate exercise and diet programme (with or without adjunctive drug therapy). There are two main categories of surgical procedures: restrictive procedures like gastric banding (fig. 1) and bypass procedures like Roux-en-Y gastric bypass (fig. 2). Restrictive surgery aims to prevent excessive food consumption by reducing the volume of the stomach and reducing appetite [12]. At present, the Roux-en-Y gastric bypass procedure is widely accepted to be the gold standard of bariatric surgery $[13,14]$. Here, a small stomach pouch is created and connected to the distal small intestine. The upper part of the small intestine is then reattached in a Y-shaped configuration (fig. 2).

Generally, gastric banding results in a weight loss of approximately $20 \%$, whilst the Roux-en-Y gastric bypass results

\section{KARGER}

Fax +497614520714

Information@Karger.de

www.karger.com (c) 2009 S. Karger GmbH, Freiburg

Accessible online at:

www.karger.com/ofa
Dr. Carel W. le Roux, MBChB, Ph.D., MRCP, MRCPath

Department of Investigative Medicine

Hammersmith Hospital, Imperial College London

Du Cane Road, London, W12 0NN, UK

Tel. +442083833242

c.leroux@imperial.ac.uk 


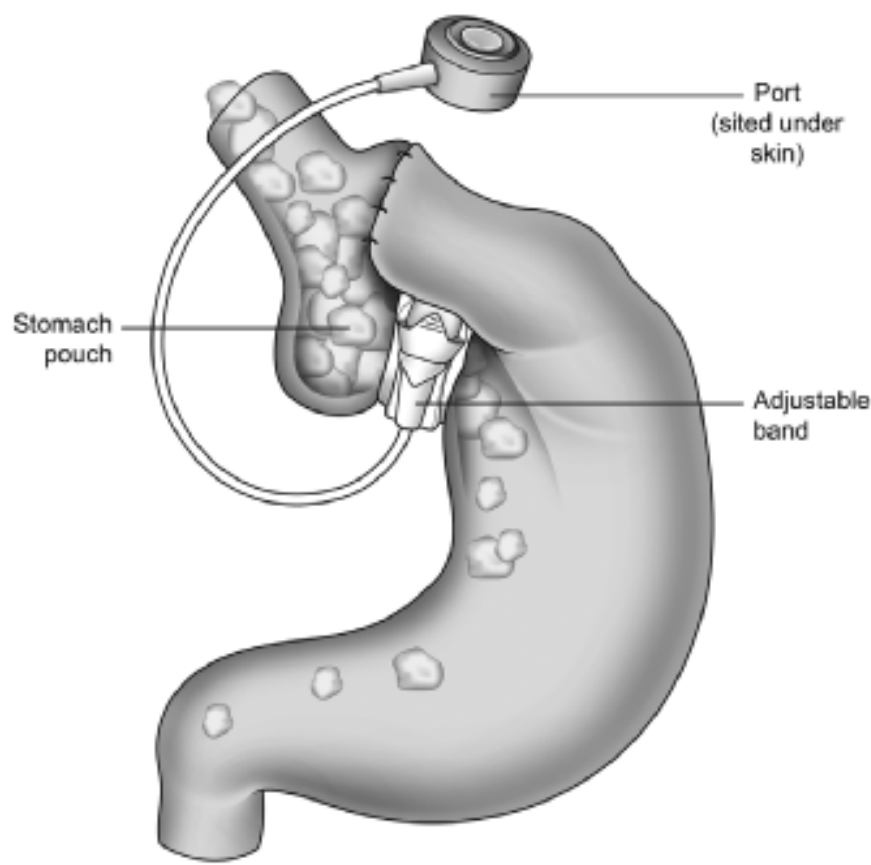

Fig. 1. Gastric banding (pouch size: $10-20 \mathrm{ml}$ ).

in approximately $25 \%$ weight loss [15]. Overall, the bypass procedures induce greater weight loss than restrictive procedures [8] and are characterised by an immediate and prolonged loss of appetite. Furthermore, weight loss after bypasstype procedures results from reduced appetite and calorie intake rather than malabsorption [16]. Several studies report a dramatic improvement of obesity-related comorbidities and a significant decrease in mortality after bariatric surgery [7, $8,17]$. Surgery is still associated with risks and adverse effects after gastric bypass. These include dumping syndrome in about $20 \%$ of patients, anastomotic leakage (1-2\%), incisional hernia $(7 \%)$, infections $(6 \%)$, deep vein thrombosis (1-3\%) [18], pulmonary embolism (2\%) [19], and pneumonia (4\%) [20]. To reduce the incidence of complications, patients should be treated in high-volume centres with clinicians experienced in bariatric surgery [21].

\section{Appetite Regulation via the Gut-Brain Axis}

The hypothalamus as part of the central melanocortin system plays a crucial role in the regulation of food intake. Several hypothalamic nuclei have been identified, all of which are interconnected by energy homoeostasis-regulating circuits [22]. Among these, the arcuate nucleus (ARC) acts as an important relay centre. The ARC can be functionally divided into a medial and a lateral part. Both parts integrate and distribute peripheral information from hormonal and neural signals that reflect metabolic status of the periphery to the brain [23, 24]. Neurons within the medial ARC co-express neuropeptide Y (NPY) and agouti-related peptide, which stimulates

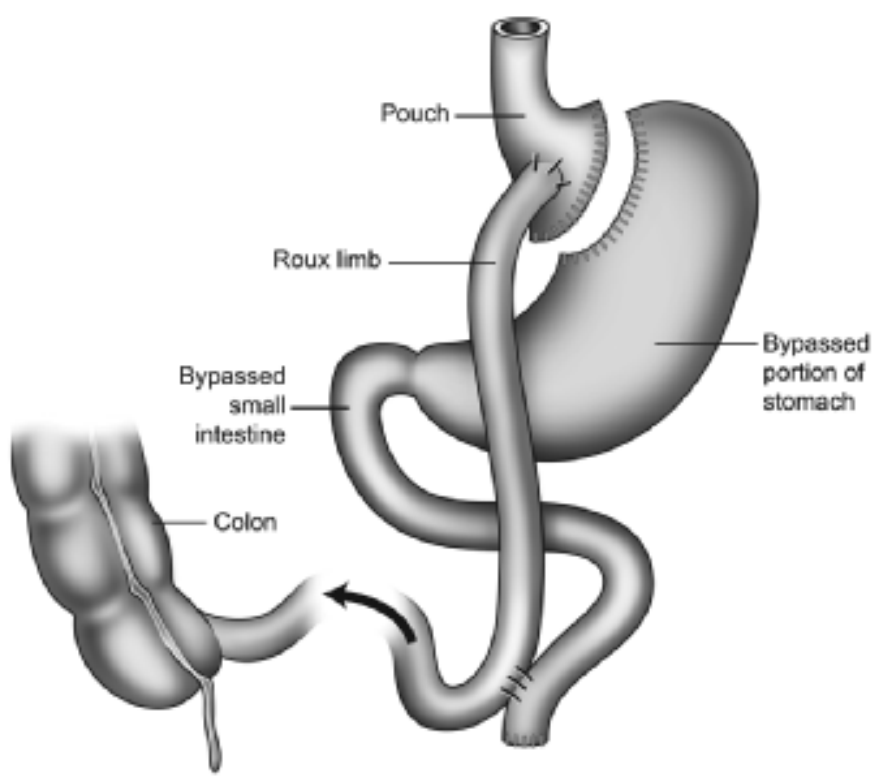

Fig. 2. Roux-en-Y gastric bypass (pouch size: 10-20 ml).

food intake and weight gain by increasing appetite [24]. The neurons in the lateral ARC co-express pro-opiomelanocortin (POMC) and cocaine- and amphetamine-regulated transcript, which both promote weight loss by decreasing appetite [23]. Furthermore, NPY can also suppress appetite and is a selective ligand for the Y4 receptor subtype which is expressed at the area postrema (AP) and the other appetite-regulating areas of the melanocortin pathway $[25,26]$. The balance between the activities of NPY-POMC neuronal circuits is critical for the maintenance of body weight [23, 24, 27]. Due to its immediate vicinity to brain regions with an incomplete blood-brain area, the ARC and the brainstem are ideally located to receive incoming signals from the periphery [24]. Humoral signals from the periphery may be well delivered by gut hormones crossing the blood-brain barrier through the circumventricular organs after being released into the circulation. Sensory input to the CNS is also forwarded by vagal and somatosensory afferent fibres in the gastrointestinal tract all ending centrally in the nucleus tractus solitarius (NTS) within the brainstem.

Information about energy stores and recent food intake is mutually exchanged between the hypothalamus and brainstem, influencing the perception of satiety [24]. When communication with higher brain centres is surgically interrupted, these brain centres can still respond independently to peripheral signals [28].

\section{Gastrointestinal Hormones}

The gut-brain axis is a major component of appetite regulation. Gastrointestinal hormones have either an orexigenic or anorexigenic action on food intake, and their levels are altered 
Table 1. Origin, effects, and altered levels of gastrointestinal hormones after bariatric surgery

\begin{tabular}{|c|c|c|c|c|c|c|}
\hline \multirow{2}{*}{$\begin{array}{l}\text { Gastrointestinal } \\
\text { hormones }\end{array}$} & \multirow[t]{2}{*}{ Origin } & \multicolumn{2}{|c|}{ Behavioral brain effects } & \multirow[t]{2}{*}{ Other effects } & \multicolumn{2}{|c|}{ Alterations after surgery } \\
\hline & & hunger & satiety & & gastric bypass & gastric banding \\
\hline Ghrelin & stomach & $\uparrow$ & $\downarrow$ & unknown & unclear & unclear \\
\hline $\begin{array}{l}\text { Glucagon-like } \\
\text { peptide-1 }\end{array}$ & ileum (L-cell) & $\downarrow$ & unknown & $\begin{array}{l}\text { insulin secretion } \uparrow \\
\beta \text {-cell proliferation } \uparrow \\
\beta \text {-cell gene expression } \uparrow \\
\text { gastric acid secretion } \downarrow \\
\text { gastric emptying } \downarrow \\
\text { apoptosis } \downarrow\end{array}$ & $\uparrow$ & no change \\
\hline Peptide YY & ileum (L-cell) & $\downarrow$ & $\uparrow$ & $\begin{array}{l}\text { gastric acid secretion } \downarrow \\
\text { pancreatic and intestinal secretion } \downarrow \\
\text { gastrointestinal motility } \downarrow\end{array}$ & $\uparrow$ & no change \\
\hline $\begin{array}{l}\text { Gastric inhibitory } \\
\text { polypeptide }\end{array}$ & $\begin{array}{l}\text { duodenum and } \\
\text { jejunum (K-cell) }\end{array}$ & unknown & unknown & $\begin{array}{l}\text { fat deposition } \uparrow \\
\text { triglyceride accumulation } \uparrow \\
\text { insulin secretion } \uparrow \\
\beta \text {-cell proliferation } \uparrow \\
\text { apoptosis } \downarrow \\
\text { bone formation } \uparrow\end{array}$ & $\downarrow$ (diabetics) & unknown \\
\hline Cholecystokinin & $\begin{array}{l}\text { duodenum and } \\
\text { jejunum (I-cell) }\end{array}$ & $\downarrow$ & $\uparrow$ & $\begin{array}{l}\text { gastric emptying } \downarrow \\
\text { pancreatic secretion } \uparrow \\
\text { gall bladder contraction } \uparrow\end{array}$ & no change & no change \\
\hline $\begin{array}{l}\text { Pancreatic } \\
\text { polypetide }\end{array}$ & pancreas & $\downarrow$ & unknown & $\begin{array}{l}\text { gastric emptying } \downarrow \\
\text { leptin levels (white adipose tissue) } \downarrow\end{array}$ & no change & no change \\
\hline
\end{tabular}

after bariatric surgery [29]. The hormones that are reviewed include ghrelin, glucagon-like peptide-1 (GLP-1), peptide YY (PYY), gastric inhibitory polypeptide (GIP), cholecystokinin (CCK), and pancreatic polypeptide (PP). Table 1 summarises the origin and effects of the addressed hormones as well as their altered levels after gastric bypass and gastric banding surgery.

\section{Ghrelin}

Ghrelin is a 28-amino-acid gut peptide derived predominantly from the stomach [30]. So far, it is the only known orexigen (appetite-stimulating hormone). Ghrelin increases food intake in rodents [31] and humans [22] via the growth hormone secretagogue receptor (GSH-R). Most clinical studies have examined its potential for the treatment of conditions characterised by anorexia and cachexia [32-34]. Circulating ghrelin levels peak in the fasting state and decrease after food intake [35]. Plasma ghrelin levels seem to be primary regulated by the calorific intake [36], and it also stimulates appetite and food intake in obese individuals [37]. Ghrelin levels are lower in weight-stable obese individuals and rise after diet-induced weight loss [38]. The postprandial decrease in plasma ghrelin is absent or attenuated in the obese $[39,40]$.

\section{Glucagon-Like Peptide-1}

GLP-1 is a neuropeptide hormone which is produced by posttranslational processing of the preproglucagon gene in the CNS and the gastrointestinal tract [41]. GLP-1 is secreted from intestinal endocrine L-cells that make direct contact with the gut lumen and is therefore believed to sense the arrival and passage of nutrients along the gastrointestinal tract [41]. The brainstem is an important site of action for peripheral GLP-1, and it has been demonstrated that both peripheral and central GLP-1 administration activates neurons in the ARC, the hypothalamic paraventricular nucleus, NTS, and AP, all increasing satiety and decreasing hunger [42, 43]. GLP-1 is released after food intake, but differences have been observed between normal weight and obese individuals [44-46]. GLP-1 is a potent incretin (insulin-stimulating peptide). GLP-1 administration causes gastrointestinal side-effects including decreased gastric acid secretion and delayed gastric emptying [47, 48]. Vagotomy can resolve the gastrointestinal effects of GLP-1, indicating an important role of the vagus nerve for mediating its anorectic effects [42].

The effects of GLP-1 in reducing appetite and calorie intake in humans have been shown to occur in a dose-dependent manner $[49,50]$. Increased energy expenditure by raising body temperature $[51,52]$ and regulating lipogenesis $[53,54]$ have been suggested to be part of GLP-1's central actions, while some studies suggest its role in promoting lipolysis [54]. Subcutaneous GLP-1 treatment improves glycaemic control in patients with type 2 diabetes mellitus (T2DM) within 3 weeks [55], while the GLP-1 agonist exenatide improves HbA1c levels in the long term [56]. In addition, GLP-1 increases pancreatic $\beta$-cell gene expression, promotes $\beta$-cell proliferation, and inhibits apoptosis [57]. 


\section{Peptide $Y Y$}

PYY is a 36-amino-acid peptide and a member of the pancreatic polypeptide family [58]. PYY levels are highest in the colon and rectum and diminish to lower levels in the small intestine [59]. As is the case for GLP-1, PYY is stored and released from L-cells of the gastrointestinal tract [59, 60]. PYY is secreted in proportion to calories ingested and independent of gastric distension [59]. PYY inhibits gastric, pancreatic, and intestinal secretion as well as gastrointestinal motility [59, 61]. The major form of circulating PYY is the N-terminally truncated PYY3-36, which has high affinity for the Y2 receptor and a lesser affinity for Y1 and Y5 receptors [62]. Although initially controversial, peripheral administration of PYY3-36 at physiological doses has now been accepted to reduce food intake in rodents, primates, and humans in the short term [6366]. PYY3-36 activates anorectic POMC-expressing neurons in the ARC, and direct intra-ARC administration of PYY3-36 reduces food intake in rats [67]. It has been demonstrated for both PYY and GLP-1 that ablation of the vagus-brainstemhypothalamus pathway leads to a moderation of their anorectic effects [42]. Obese individuals are sensitive to the effects of PYY, as peripheral PYY administration in obesity reduces food intake to the same extent as in normal weight individuals, but circulating postprandial PYY levels are lower in the obese [68]. Hence, exogenous administration of PYY3-36 has attracted considerable interest as a possible therapeutic strategy [69]. Long-term augmentation of dietary protein induces an increase of plasma PYY levels in mice, leading to less food intake and reduced adiposity [70]. PYY3-36 administration in humans at levels above physiological ranges results in nausea $[67,68]$, although this does not occur within its physiological range [64]. Elevated fasting levels of PYY can also be found in gastrointestinal diseases associated with appetite loss, including inflammatory bowel disease (IBD), steatorrhea due to small intestinal mucosal atrophy, and chronic destructive pancreatitis [71].

\section{Gastric Inhibitory Polypeptide}

GIP is a 42-amino-acid peptide released from duodenal and jejunal K-cells after ingestion of nutrients [72]. GIP is also known as glucose-dependent insulinotropic polypeptide. GIP facilitates the dispersion of both glucose and fat [73] and aids fat deposition and triglyceride accumulation in adipocytes. The peptides exert several anabolic adipocyte actions as well as lipolytic effects $[73,74]$. GIP receptor-deficient mice (GIPR-/-) have lower adipocyte mass and are completely resistant to diet-induced obesity [75]. GIP on its own has no acute impact on food intake [72], but acts in concert with GLP-1 to control food intake and energy absorption. Similar to GLP-1, GIP increases glucose-dependent insulin secretion, $\beta$-cell proliferation, and resistance to apoptosis [76]. GIP enhances bone formation via stimulation of osteoblast proliferation and inhibition of apoptosis. Its levels are raised in obesity [72].

\section{Cholecystokinin}

CCK was first shown to inhibit food intake nearly 30 years ago [77]. It is widely distributed within the gastrointestinal tract, but most CCK is synthesised in the duodenum and jejunum in response to the presence of nutrients [78]. CCK is an active peptide that is derived from numerous posttranslational modifications of pro-CCK. Several gastrointestinal functions are mediated by CCK, including the delaying of gastric emptying, the stimulation of pancreatic enzyme secretion, and gall bladder contraction $[79,80]$. CCK is also involved in the regulation of food intake by acting via vagal afferents to induce satiety. Other neurotransmitters such as serotonin and noradrenaline may work in conjunction with CCK to coordinate gastrointestinal activity [81]. In healthy elderly people, high CCK and PYY levels are associated with delayed gastric emptying and reduced gallbladder contractility [82]. These high CCK and PYY levels facilitate long-lasting satiety and hunger suppression after meals and can lead to caloric restriction and malnutrition in the elderly [82].

\section{Pancreatic Polypeptide}

PP belongs to a family of peptides including NPY and PYY. $\mathrm{PP}$ is released from the pancreas in response to ingestion of food. Plasma PP has been shown to be reduced in conditions associated with increased food intake and elevated in anorexia nervosa [83]. Intravenously administered PP induces negative energy balance by decreasing food intake and gastric emptying while increasing energy expenditure. The mechanism of PP action involves modification of expression of feeding-regulatory peptides (decrease in orexigenic NPY, orexin, and ghrelin along with an increase in anorexigenic urocortin) and activity of the vagovagal or vagosympathetic reflex arc. $\mathrm{PP}$ reduces leptin in white adipose tissue and ACTH-releasing factor gene expression [84].

\section{Gut Hormones and Appetite after Bariatric Surgery}

Studies on gastrointestinal hormones after bariatric surgery can provide further information on the complex mechanisms of appetite regulation, satiety, and energy expenditure. Changes in appetite are reported within days following bariatric surgery [10]. Postprandial levels of gastrointestinal hormones that induce satiety, such as GLP-1 and PYY, are elevated after gastric bypass surgery [9], but not after gastric banding [29]. An optimally inflated gastric band reduces hunger and elevates satiety [12], but changes in appetite are independent of gut hormone alterations [29]. Furthermore, octreotide administration does not inhibit food intake in patients with gastric bands, indicating that gut hormone responses are absent [29]. Therefore, non-hormonal mechanisms have been suggested to reduce hunger following gastric banding [29]. In contrast, several studies have demonstrated that postprandial PYY and GLP-1 levels start rising as early as 2 days after gas- 
tric bypass and remain elevated for many months after surgery $[10,11]$. PYY and GLP-1 responses seem to correlate with different levels of weight loss: patients with $20 \%$ weight loss after gastric bypass operations show lower PYY and GLP1 levels compared with patients that have lost $40 \%$ of their weight after surgery [10]. Moreover, appetite and food intake can be increased by administration of octreotide after gastric bypass, suggesting an inhibition of the satiety gastrointestinal hormone response [10]. The proposed mechanism behind these findings is that bariatric surgery stimulates the distal Lcells to secrete gastrointestinal hormones such as PYY and the enteroglucagon family of peptides [29]. As a result, patients have long-term decreased appetite after gastric bypass. The combination of gastrointestinal hormone responses might contribute to the successful weight loss and its maintenance after bariatric surgery, as the combined effect of exogenous elevation of PYY and GLP-1 reduces food intake more than predicted by individual hormone infusions alone [85].

In contrast, changes in ghrelin levels after bariatric surgery are more controversial. Cummings et al. [38] described markedly suppressed ghrelin levels after gastric bypass while dietinduced weight loss was associated with increased levels of plasma ghrelin. The suggestion was that reduced ghrelin contributes to the weight loss after gastric bypass [38], but conflicting results have been published [86-90]. Thus, the role of ghrelin after gastric bypass remains unclear. Ghrelin secretion might in fact be modified by other gastrointestinal hormones whose levels change in response to the altered gastrointestinal anatomy. However, since obesity is associated with lower levels of ghrelin, it seems unlikely that reducing the level of ghrelin would, by itself, induce weight loss [91].
Less is known about changes in GIP, CCK, and PP levels after bariatric surgery. While both CCK and PP levels seem to be unaltered following bariatric surgery [10, 92], GIP levels are significantly reduced in diabetic patients following bypass surgery [93]. However, no changes in GIP levels were found in non-diabetics [93].

Long-term follow-up data on the changes in gastrointestinal hormones after bariatric surgery are still awaited. Surgery modulates a number of gut hormones and probably allows them to act in concert in such a way as to affect appetite optimally. Understanding the contribution each hormone makes to appetite control within the setting of gastric bypass surgery may be the stepping stone to future anti-obesity treatments.

\section{Conclusions}

Gastric bypass surgery is associated with elevated satiety and satiety-inducing gut hormones. The satiety effects can be reversed by blocking the hormonal responses. Bariatric surgery is currently the only therapy inducing significant and sustained weight loss, but surgery carries the risk for serious complications. Thus, bariatric surgery may be used as a model to examine the physiological mechanisms of weight loss and to develop future surgical and non-surgical weight loss treatments.

\section{Disclosure}

The authors declared no conflict of interests.

\section{References}

1 Allison DB, Saunders SE: Obesity in North America. An overview. Med Clin North Am 2000;84:305$332, \mathrm{v}$.

$>2$ Hedley AA, Ogden CL, Johnson CL, Carroll MD, Curtin LR, Flegal KM: Prevalence of overweight and obesity among US children, adolescents, and adults, 1999-2002. JAMA 2004;291:2847-2850.

3 Visscher TL, Seidell JC: The public health impact of obesity. Annu Rev Public Health 2001;22:355375.

4 Kaplan LM: Pharmacological therapies for obesity. Gastroenterol Clin North Am 2005;34:91-104.

$\checkmark 5$ Thearle M, Aronne LJ: Obesity and pharmacologic therapy. Endocrinol Metab Clin North Am 2003; 32:1005-1024

6 Yanovski SZ, Yanovski JA: Obesity. N Engl J Med 2002;346:591-602.

7 Adams TD, Gress RE, Smith SC, Halverson RC, Simper SC, Rosamond WD, Lamonte MJ, Stroup AM, Hunt SC: Long-term mortality after gastric bypass surgery. N Engl J Med 2007;357:753-761.
8 Sjöström L, Narbro K, Sjöström CD, Karason K, Larsson B, Wedel H, Lystig T, Sullivan M, Bouchard C, Carlsson B, Bengtsson C, Dahlgren S, Gummesson A, Jacobson P, Karlsson J, Lindroos AK, Lönroth H, Näslund I, Olbers T, Stenlöf K, Torgerson J, Agren G, Carlsson LM: Effects of bariatric surgery on mortality in Swedish obese subjects. N Engl J Med 2007;357:741-752.

$\checkmark 9$ Borg CM, le Roux CW, Ghatei MA, Bloom SR, Patel AG, Aylwin SJ: Progressive rise in gut hormone levels after Roux-en-Y gastric bypass suggests gut adaptation and explains altered satiety. Br J Surg 2006;93:210-215.

10 le Roux CW, Welbourn R, Werling M, Osborne A, Kokkinos A, Laurenius A, Lönroth H, Fändriks L, Ghatei MA, Bloom SR, Olbers T: Gut hormones as mediators of appetite and weight loss after Rouxen-Y gastric bypass. Ann Surg 2007;246:780-785.

11 Näslund E, Grybäck P, Hellström PM, Jacobsson H, Holst JJ, Theodorsson E, Backman L: Gastrointestinal hormones and gastric emptying 20 years after jejunoileal bypass for massive obesity. Int $\mathrm{J}$ Obes Relat Metab Disord 1997;21:387-392.

12 Dixon AF, Dixon JB, O’Brien PE: Laparoscopic adjustable gastric banding induces prolonged satiety: a randomized blind crossover study. J Clin Endocrinol Metab 2005;90:813-819.
13 Buchwald H, Husemann B, Leutenegger AF, Mason EE, Rothmund M, Siewert JR: Morbid obesity - surgical treatment - when and how? Langenbecks Arch Chir 1986;368:73-79.

14 Buchwald H: Bariatric surgery for morbid obesity: health implications for patients, health professionals, and third-party payers. J Am Coll Surg 2005;200: 593-604.

15 Maggard MA, Shugarman LR, Suttorp M, Maglione M, Sugerman HJ, Livingston EH, Nguyen NT, Li Z, Mojica WA, Hilton L, Rhodes S, Morton SC, Shekelle PG: Meta-analysis: surgical treatment of obesity. Ann Intern Med 2005;142:547-559.

-16 Pilkington TR, Gazet JC, Ang L, Kalucy RS, Crisp AH, Day S: Explanations for weight loss after ileojejunal bypass in gross obesity. Br Med J 1976;1:1504-1505.

17 Sjöström L, Lindroos AK, Peltonen M, Torgerson J, Bouchard C, Carlsson B, Dahlgren S, Larsson B, Narbro K, Sjöström CD, Sullivan M, Wedel H: Lifestyle, diabetes, and cardiovascular risk factors 10 years after bariatric surgery. N Engl J Med 2004:351:2683-2693.

18 Ojo P, Asiyanbola B, Valin E, Reinhold R: Post discharge prophylactic anticoagulation in gastric bypass patient - how safe? Obes Surg 2008;18:791-796. 
19 Westling A, Bergqvist D, Boström A, Karacagil S, Gustavsson S: Incidence of deep venous thrombosis in patients undergoing obesity surgery. World $\mathrm{J}$ Surg 2002;26:470-473.

20 Encinosa WE, Bernard DM, Chen CC, Steiner CA: Healthcare utilization and outcomes after bariatric surgery. Med Care 2006;44:706-712.

21 Flum DR, Salem L, Elrod JA, Dellinger EP, Cheadle A, Chan L: Early mortality among Medicare beneficiaries undergoing bariatric surgical procedures. JAMA 2005;294:1903-1908.

22 Wren AM, Seal LJ, Cohen MA, Brynes AE, Frost GS, Murphy KG, Dhillo WS, Ghatei MA, Bloom SR: Ghrelin enhances appetite and increases food intake in humans. J Clin Endocrinol Metab 2001; 86:5992.

23 Cone RD, Cowley MA, Butler AA, Fan W, Marks DL, Low MJ: The arcuate nucleus as a conduit for diverse signals relevant to energy homeostasis. Int J Obes Relat Metab Disord 2001;25(suppl 5):S63-S67.

24 Schwartz MW, Woods SC, Porte D, Jr, Seeley RJ, Baskin DG: Central nervous system control of food intake. Nature 2000;404:661-671.

25 Balasubramaniam A, Mullins DE, Lin S, Zhai W, Tao Z, Dhawan VC, Guzzi M, Knittel JJ, Slack K, Herzog H, Parker EM: Neuropeptide Y (NPY) Y4 receptor selective agonists based on NPY(32-36): development of an anorectic Y4 receptor selective agonist with picomolar affinity. J Med Chem 2006;49: 2661-2665.

26 Larsen PJ, Kristensen P: The neuropeptide Y (Y4) receptor is highly expressed in neurones of the rat dorsal vagal complex. Brain Res Mol Brain Res 1997; 48:1-6.

27 Flier JS: Obesity wars: molecular progress confronts an expanding epidemic. Cell 2004;116:337-350.

28 Grill HJ, Smith GP: Cholecystokinin decreases sucrose intake in chronic decerebrate rats. Am J Physiol 1988;254:R853-R856.

29 le Roux CW, Aylwin SJ, Batterham RL, Borg CM, Coyle F, Prasad V, Shurey S, Ghatei MA, Patel AG, Bloom SR: Gut hormone profiles following bariatric surgery favor an anorectic state, facilitate weight loss, and improve metabolic parameters. Ann Surg 2006;243:108-114.

>30 Murakami N, Hayashida T, Kuroiwa T, Nakahara K, Ida T, Mondal MS, Nakazato M, Kojima M, Kangawa K: Role for central ghrelin in food intake and secretion profile of stomach ghrelin in rats. $\mathrm{J}$ Endocrinol 2002;174:283-288.

-31 Wren AM, Small CJ, Abbott CR, Dhillo WS, Seal LJ, Cohen MA, Batterham RL, Taheri S, Stanley SA Ghatei MA, Bloom SR: Ghrelin causes hyperphagia and obesity in rats. Diabetes 2001;50:2540-2547.

32 Nagaya N, Moriya J, Yasumura Y, Uematsu M, Ono F, Shimizu W, Ueno K, Kitakaze M, Miyatake $\mathrm{K}$, Kangawa K: Effects of ghrelin administration on left ventricular function, exercise capacity, and muscle wasting in patients with chronic heart failure. Circulation 2004;110:3674-3679.

33 Nagaya N, Itoh T, Murakami S, Oya H, Uematsu M, Miyatake K, Kangawa K: Treatment of cachexia with ghrelin in patients with COPD. Chest 2005;128: 1187-1193.

34 Neary NM, Small CJ, Wren AM, Lee JL, Druce MR, Palmieri C, Frost GS, Ghatei MA, Coombes RC, Bloom SR: Ghrelin increases energy intake in cancer patients with impaired appetite: acute, randomized, placebo-controlled trial. J Clin Endocrinol Metab 2004;89:2832-2836.

35 Cummings DE, Purnell JQ, Frayo RS, Schmidova $\mathrm{K}$, Wisse BE, Weigle DS: A preprandial rise in plasma ghrelin levels suggests a role in meal initiation in humans. Diabetes 2001;50:1714-1719.
36 le Roux CW, Neary NM, Halsey TJ, Small CJ, Martinez-Isla AM, Ghatei MA, Theodorou NA, Bloom SR: Ghrelin does not stimulate food intake in patients with surgical procedures involving vagotomy. J Clin Endocrinol Metab 2005;90:4521-4524.

37 Druce MR, Wren AM, Park AJ, Milton JE, Patterson M, Frost G, Ghatei MA, Small C, Bloom SR: Ghrelin increases food intake in obese as well as lean subjects. Int J Obes (Lond) 2005;29:1130-1136.

38 Cummings DE, Weigle DS, Frayo RS, Breen PA, Ma MK, Dellinger EP, Purnell JQ: Plasma ghrelin levels after diet-induced weight loss or gastric bypass surgery. N Engl J Med 2002;346:1623-1630.

39 English PJ, Ghatei MA, Malik IA, Bloom SR, Wilding JP: Food fails to suppress ghrelin levels in obese humans. J Clin Endocrinol Metab 2002; 87:2984.

40 le Roux CW, Patterson M, Vincent RP, Hunt C, Ghatei MA, Bloom SR: Postprandial plasma ghrelin is suppressed proportional to meal calorie content in normal-weight but not obese subjects. J Clin Endocrinol Metab 2005;90:1068-1071.

41 Holst JJ: On the physiology of GIP and GLP-1. Horm Metab Res 2004:36:747-754.

42 Abbott CR, Monteiro M, Small CJ, Sajedi A, Smith KL, Parkinson JR, Ghatei MA, Bloom SR: The inhibitory effects of peripheral administration of peptide YY(3-36) and glucagon-like peptide-1 on food intake are attenuated by ablation of the vagal-brainstem-hypothalamic pathway. Brain Res 2005;1044:127-131.

43 Larsen PJ, Tang-Christensen M, Jessop DS: Central administration of glucagon-like peptide-1 activates hypothalamic neuroendocrine neurons in the rat. Endocrinology 1997;138:4445-4455.

44 Feinle C, Chapman IM, Wishart J, Horowitz M: Plasma glucagon-like peptide-1 (GLP-1) responses to duodenal fat and glucose infusions in lean and obese men. Peptides 2002;23:1491-1495.

45 Fukase N, Igarashi M, Takahashi H, Manaka H, Yamatani K, Daimon M, Tominaga M, Sasaki H: Hypersecretion of truncated glucagon-like peptide- 1 and gastric inhibitory polypeptide in obese patients. Diabet Med 1993;10:44-49.

46 Verdich C, Toubro S, Buemann B, Lysgard MJ, Juul HJ, Astrup A: The role of postprandial releases of insulin and incretin hormones in meal-induced satiety - effect of obesity and weight reduction. Int J Obes Relat Metab Disord 2001;25:1206-1214.

47 Edwards CM, Todd JF, Mahmoudi M, Wang Z, Wang RM, Ghatei MA, Bloom SR: Glucagon-like peptide 1 has a physiological role in the control of postprandial glucose in humans: studies with the antagonist exendin 9-39. Diabetes 1999;48:86-93.

48 Kreymann B, Williams G, Ghatei MA, Bloom SR: Glucagon-like peptide-1 7-36: a physiological incretin in man. Lancet 1987;2:1300-1304.

49 Edwards CM, Stanley SA, Davis R, Brynes AE, Frost GS, Seal LJ, Ghatei MA, Bloom SR: Exendin-4 reduces fasting and postprandial glucose and decreases energy intake in healthy volunteers. Am J Physiol Endocrinol Metab 2001;281:E155-E161.

50 Gutzwiller JP, Goke B, Drewe J, Hildebrand P, Ketterer S, Handschin D, Winterhalder R, Conen D, Beglinger C: Glucagon-like peptide-1: a potent regulator of food intake in humans. Gut 1999;44: 81-86.

51 O'Shea D, Gunn I, Chen X, Bloom S, Herbert J: A role for central glucagon-like peptide-1 in temperature regulation. Neuroreport 1996;7:830-832.
52 Turton MD, O'Shea D, Gunn I, Beak SA, Edwards CM, Meeran K, Choi SJ, Taylor GM, Heath MM, Lambert PD, Wilding JP, Smith DM, Ghatei MA, Herbert J, Bloom SR: A role for glucagon-like peptide- 1 in the central regulation of feeding. Nature 1996;379:69-72.

53 Ruiz-Grande C, Alarcón C, Mérida E, Valverde I: Lipolytic action of glucagon-like peptides in isolated rat adipocytes. Peptides 1992;13:13-16.

54 Villanueva-Peñacarrillo ML, Márquez L, González N, Díaz-Miguel M, Valverde I: Effect of GLP-1 on lipid metabolism in human adipocytes. Horm Metab Res 2001;33:73-77.

55 Todd JF, Edwards CM, Ghatei MA, Mather HM, Bloom SR: Subcutaneous glucagon-like peptide-1 improves postprandial glycaemic control over a 3 week period in patients with early type 2 diabetes. Clin Sci (Lond) 1998;95:325-329.

56 Guerci B, Martin CS: Exenatide: its position in the treatment of type 2 diabetes. Ann Endocrinol (Paris) 2008;69:201-209.

57 Soltani N, Kumar M, Glinka Y, Prud'homme GJ, Wang Q: In vivo expression of GLP-1/IgG-Fc fusion protein enhances beta-cell mass and protects against streptozotocin-induced diabetes. Gene Ther 2007;14:981-988.

58 Tatemoto K, Mutt V: Isolation of two novel candidate hormones using a chemical method for finding naturally occurring polypeptides. Nature 1980; 285:417-418.

-59 Adrian TE, Ferri GL, Bacarese-Hamilton AJ, Fuessl HS, Polak JM, Bloom SR: Human distribution and release of a putative new gut hormone, peptide YY. Gastroenterology 1985;89:1070-1077.

60 Ali-Rachedi A, Varndell IM, Adrian TE, Gapp DA, Van Noorden S, Bloom SR, Polak JM: Peptide YY (PYY) immunoreactivity is co-stored with glucagon-related immunoreactants in endocrine cells of the gut and pancreas. Histochemistry 1984;80:487-491.

61 Allen JM, Fitzpatrick ML, Yeats JC, Darcy K, Adrian TE, Bloom SR: Effects of peptide YY and neuropeptide $\mathrm{Y}$ on gastric emptying in man. Digestion 1984;30:255-262.

62 le Roux CW, Batterham RL, Aylwin SJ, Patterson M, Borg CM, Wynne KJ, Kent A, Vincent RP, Gardiner J, Ghatei MA, Bloom SR: Attenuated peptide YY release in obese subjects is associated with reduced satiety. Endocrinology 2006;147:3-8.

63 Chelikani PK, Haver AC, Reidelberger RD: Intravenous infusion of peptide YY(3-36) potently inhibits food intake in rats. Endocrinology 2005;146:879-888.

64 Degen L, Oesch S, Casanova M, Graf S, Ketterer S, Drewe J, Beglinger C: Effect of peptide YY3-36 on food intake in humans. Gastroenterology 2005;129: 1430-1436.

65 Koegler FH, Enriori PJ, Billes SK, Takahashi DL, Martin MS, Clark RL, Evans AE, Grove KL, Cameron JL, Cowley MA: Peptide YY(3-36) inhibits morning, but not evening, food intake and decreases body weight in rhesus macaques. Diabetes 2005;54:3198-3204.

66 Tschöp M, Castañeda TR, Joost HG, ThöneReineke C, Ortmann S, Klaus S, Hagan MM, Chandler PC, Oswald KD, Benoit SC, Seeley RJ, Kinzig KP, Moran TH, Beck-Sickinger AG, Koglin N, Rodgers RJ, Blundell JE, Ishii Y, Beattie AH, Holch P, Allison DB, Raun K, Madsen K, Wulff BS, Stidsen CE, Birringer M, Kreuzer OJ, Schindler M, Arndt K, Rudolf K, Mark M, Deng XY, Whitcomb DC, Halem H, Taylor J, Dong J, Datta R, Culler M, Craney S, Flora D, Smiley D, Heiman ML: Physiology: does gut hormone PYY3-36 decrease food intake in rodents? Nature 2004:430:1. 
67 Batterham RL, Cowley MA, Small CJ, Herzog H, Cohen MA, Dakin CL, Wren AM, Brynes AE, Low MJ, Ghatei MA, Cone RD, Bloom SR: Gut hormone PYY(3-36) physiologically inhibits food intake. Nature 2002;418:650-654.

68 Batterham RL, Cohen MA, Ellis SM, le Roux CW, Withers DJ, Frost GS, Ghatei MA, Bloom SR: Inhibition of food intake in obese subjects by peptide YY3-36. N Engl J Med 2003;349:941-948.

69 White NE, Dhillo WS, Liu YL, Small CJ, Kennett GA, Gardiner JV, Ghatei MA, Bloom SR: Co-administration of SR141716 with peptide YY3-36 or oxyntomodulin has additive effects on food intake in mice. Diabetes Obes Metab 2008;10:167-170.

70 Batterham RL, Heffron H, Kapoor S, Chivers JE, Chandarana K, Herzog H, le Roux CW, Thomas EL, Bell JD, Withers DJ: Critical role for peptide YY in protein-mediated satiation and body-weight regulation. Cell Metab 2006;4:223-233.

71 Adrian TE, Savage AP, Bacarese-Hamilton AJ, Wolfe K, Besterman HS, Bloom SR: Peptide YY abnormalities in gastrointestinal diseases. Gastroenterology 1986;90:379-384.

72 Baggio LL, Drucker DJ: Biology of incretins: GLP1 and GIP. Gastroenterology 2007;132:2131-2157.

73 Creutzfeldt W, Ebert R, Willms B, Frerichs H, Brown JC: Gastric inhibitory polypeptide (GIP) and insulin in obesity: increased response to stimulation and defective feedback control of serum levels. Diabetologia 1978;14:15-24

74 Salera M, Giacomoni P, Pironi L, Cornia G, Capelli M, Marini A, Benfenati F, Miglioli M, Barbara L: Gastric inhibitory polypeptide release after oral glucose: relationship to glucose intolerance, diabetes mellitus, and obesity. J Clin Endocrinol Metab 1982;55:329-336.

75 Miyawaki K, Yamada Y, Ban N, Ihara Y, Tsukiyama K, Zhou H, Fujimoto S, Oku A, Tsuda K, Toyokuni S, Hiai H, Mizunoya W, Fushiki T, Holst JJ, Makino M, Tashita A, Kobara Y, Tsubamoto Y, Jinnouchi T, Jomori T, Seino Y: Inhibition of gastric inhibitory polypeptide signaling prevents obesity. Nat Med 2002;8:738-742.
76 Ding WG, Gromada J: Protein kinase A-dependent stimulation of exocytosis in mouse pancreatic betacells by glucose-dependent insulinotropic polypeptide. Diabetes 1997;46:615-621.

77 Gibbs J, Young RC, Smith GP: Cholecystokinin decreases food intake in rats. J Comp Physiol Psychol 1973;84:488-495.

78 Liddle RA, Goldfine ID, Rosen MS, Taplitz RA, Williams JA: Cholecystokinin bioactivity in human plasma. Molecular forms, responses to feeding, and relationship to gallbladder contraction. J Clin Invest 1985;75:1144-1152.

79 Dockray GJ: Peptides of the gut and brain: the cholecystokinins. Proc Nutr Soc 1987:46:119-124.

80 Moran TH: Cholecystokinin and satiety: current perspectives. Nutrition 2000;16:858-865.

81 Chua AS, Keeling PW: Cholecystokinin hyperresponsiveness in functional dyspepsia. World J Gastroenterol 2006;12:2688-2693.

82 Di F, V, Zamboni M, Dioli A, Zoico E, Mazzali G, Omizzolo F, Bissoli L, Solerte SB, Benini L, Bosello O: Delayed postprandial gastric emptying and impaired gallbladder contraction together with elevated cholecystokinin and peptide YY serum levels sustain satiety and inhibit hunger in healthy elderly persons. J Gerontol A Biol Sci Med Sci 2005;60:1581-1585.

83 Batterham RL, le Roux CW, Cohen MA, Park AJ, Ellis SM, Patterson M, Frost GS, Ghatei MA, Bloom SR: Pancreatic polypeptide reduces appetite and food intake in humans. J Clin Endocrinol Metab 2003;88:3989-3992.

84 Asakawa A, Inui A, Kaga T, Katsuura G, Fujimiya M, Fujino MA, Kasuga M: Antagonism of ghrelin receptor reduces food intake and body weight gain in mice. Gut 2003;52:947-952.

85 Neary NM, Small CJ, Druce MR, Park AJ, Ellis SM, Semjonous NM, Dakin CL, Filipsson K, Wang F, Kent AS, Frost GS, Ghatei MA, Bloom SR: Peptide YY3-36 and glucagon-like peptide17-36 inhibit food intake additively. Endocrinology 2005;146:5120-5127.
86 Couce ME, Cottam D, Esplen J, Schauer P, Burguera $\mathrm{B}$ : Is ghrelin the culprit for weight loss after gastric bypass surgery? A negative answer. Obes Surg 2006;16:870-878

87 Holdstock C, Engström BE, Ohrvall M, Lind L, Sundbom M, Karlsson FA: Ghrelin and adipose tissue regulatory peptides: effect of gastric bypass surgery in obese humans. J Clin Endocrinol Metab 2003;88:3177-3183.

88 Lee H, Te C, Koshy S, Teixeira JA, Pi-Sunyer FX, Laferrere B: Does ghrelin really matter after bariatric surgery? Surg Obes Relat Dis 2006;2:538-548.

89 Mancini MC, Costa AP, de Melo ME, Cercato C Giannella-Neto D, Garrido AB, Jr, Rosberg S, Albertsson-Wikland K, Villares SM, Halpern A: Effect of gastric bypass on spontaneous growth hormone and ghrelin release profiles. Obesity (Silver Spring) 2006;14:383-387.

90 Stenstrom B, Zhao CM, Tømmerås K, Arum CJ, Chen D: Is gastrin partially responsible for body weight reduction after gastric bypass? Eur Surg Res 2006;38:94-101.

91 Rubino F, Gagner M: Weight loss and plasma ghrelin levels. N Engl J Med 2002;347:1379-1381.

92 Kellum JM, Kuemmerle JF, O'Dorisio TM, Rayford P, Martin D, Engle K, Wolf L, Sugerman HJ: Gastrointestinal hormone responses to meals before and after gastric bypass and vertical banded gastroplasty. Ann Surg 1990;211:763-770.

93 Rubino F, Gagner M, Gentileschi P, Kini S, Fukuyama S, Feng J, Diamond E: The early effect of the Roux-en-Y gastric bypass on hormones involved in body weight regulation and glucose metabolism. Ann Surg 2004;240:236-242. 